\title{
Instant blend from cassava derivatives produced by extrusion
}

\author{
Mistura instantânea de derivados de mandioca produzida por extrusão
}

\author{
Fernanda Rossi Moretti Trombini ${ }^{\mathrm{I}}$ Martha Maria Mischan ${ }^{\mathrm{II}}$ Magali Leonel $^{\mathrm{III}}$
}

\section{ABSTRACT}

The current research aimed to evaluate the effects of extrusion parameters on the physical characteristics of extruded blends of cassava leaf flour and starch. A factorial central composite design with four independent variables and the response surface methodology were used to evaluate the results of color parameters $\left(L^{*}, a^{*}, b^{*}\right)$, water absorption index, water solubility index and paste properties, according to the variations in the leaf flour percentage (1.5 to $7.5 \%$ ), extrusion temperature (60 to $\left.100^{\circ} \mathrm{C}\right)$, screw speed (175 to 231rpm) and moisture (20 to 30\%). Extrusion conditions affect color, water absorption and water solubility indexes and paste properties of blends. The intermediate tested conditions of variable parameters lead to obtain extruded products with higher cold viscosity and water absorption index and light color, desirable qualities for rapid preparation products.

Key words: leaves, starch, color, water absorption, viscosity.

\section{RESUMO}

Este trabalho teve por objetivo avaliar os efeitos dos parâmetros de extrusão sobre as características físicas de misturas extrusadas de farinha de folhas de mandioca e amido. $O$ delineamento central composto rotacional, com quatro variáveis independentes, e a metodologia de superficie de resposta foram utilizados para avaliar os resultados dos parâmetros de cor $\left(L^{*}\right.$, $\left.a^{*}, b^{*}\right)$, indice de absorção de água, indice de solubilidade em água e propriedades de pasta, de acordo com as variações da percentagem de farinha de folha (1,5 a 7,5\%), da temperatura de extrusão $\left(60\right.$ a $\left.100^{\circ} \mathrm{C}\right)$, da rotação da rosca (175-231rpm) e da umidade (20 a 30\%). As condições do processo de extrusão afetaram a cor, os índices de absorção de água e solubilidade em água e as propriedades de pasta das misturas. As intermediárias testadas dos parâmetros variáveis levaram à obtenção de produtos extrusados com maior viscosidade fria e índice de absorção de água e de cor clara, qualidades desejáveis para produtos de preparação rápida.

Palavras-chave: folhas, amido, cor, absorção de água, viscosidade.

\section{INTRODUCTION}

Extrusion cooking is a continuous process in one-step that combines shear forces, high pressure and high temperature in short time (BERK, 2009;VARGAS-SOLÓRZANO et al., 2014) and it is one of several different processes used to produce instant blends. This technique has some unique positive features compared with other heat processes, because the material is subject to intense mechanical shear. It is able to break the covalent bonds in biopolymers, and intense structural disruption and mixing facilitate the modification of functional properties of food ingredients. In addition, from a nutritional point of view, extrusion cooking allows inactivation of certain antinutritional factors (MOUQUET et al., 2003; SINGH et al., 2007; BERRIOS et al., 2013).

An instant product usually is presented as a powder mix and is characterized by its quick preparation when immersed in a liquid (water or milk). The instant term can also be used to describe

'Programa de Pós-graduação em Energia na Agricultura, Faculdade de Ciências Agronômicas (FCA), Universidade Estadual Paulista "Júlio de Mesquita Filho" (UNESP), Botucatu, SP, Brasil.

"Departamento de Bioestatística, Instituto de Biociências (IB), UNESP, Distrito de Rubião Júnior, Botucatu, SP, Brasil.

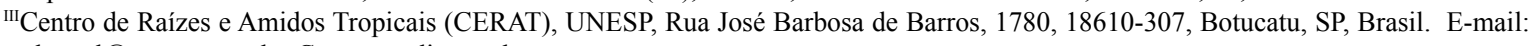
mleonel@cerat.unesp.br. Corresponding author. 
food powder which is easily miscible in cold water (VISSOTTO et al., 2006). To increase the protein content and improve the nutritive value of extruded products, various sources of protein and fibers may be added to their formulation. Enrichment of this kind of food is of great interest for consumers (PÉREZ et al., 2008; TAVERNA et al.; 2012; SPINELLO et al., 2014).

Brazil is the third largest world producer of cassava (23.35 million tons) with a wide variety of farming systems. The industrial sector of cassava processing is now seeking access to new markets, either through creating new uses for cassava derivatives or through developing new products.

Cassava leaves are good source of nutrients which enables its application as an ingredient for food industry. Despite high levels of protein, fiber, minerals and vitamins, cassava leaves contain cyanide, a toxic substance that prevents their consumption "in natura" (FERRARI et al., 2014). Democratic Republic of Congo is the most import producer of cassava leaves with an estimated production of 85,007 tons (FAO, 2014). In that country roots and leaves are both consumed and have almost equal importance in the population diet. Differently of Congo, in Brazil cassava leaves have yet been little exploited for human food, especially because of the lack of knowledge of their nutritional value and also due to the economic feasibility of commercial exploitation. A large amount of cassava leaves are wasted during root harvest in all regions of Brazil. It is estimated that for an area of 158 million hectares, more than 178,000 tons of leaves are lost each year.

Aiming to enhance the products derived from cassava as raw materials for food industry this study evaluated physical properties of extruded blends of cassava starch and cassava leaf flour for use as instant products.

\section{MATERIAL AND METHODS}

The raw materials used in this study included commercial cassava starch (Lotus Comércio e Indústria de Mandioca Ltda, Cândido Mota-SP, Brazil) and cassava leaf flour.

To produce cassava leaf flour, cassava leaves obtained from cultivar IAC 13 were harvested at 12 months after cassava planting and were washed with water. The leaves were dried in an oven with air circulation at a temperature of $50^{\circ} \mathrm{C}$ for $24 \mathrm{~h}$. After drying, the material was ground using knife mill (MA680 - Marconi, Brazil) to obtain the flour.
The chemical composition of commercial cassava starch was $13 \%$ of moisture, $1.4 \%$ of ash, $0.4 \%$ of crude fiber, $0.6 \%$ of lipids, $0.2 \%$ of protein and $84 \%$ of total carbohydrates. The cassava leaf flour composition was: $9 \%$ of moisture, $6 \%$ of ash, $26 \%$ of crude fiber, $14 \%$ of lipids, $23 \%$ of protein and $21 \%$ of total carbohydrates.

Mixtures of sour cassava starch and cassava leaf flour were prepared and after homogenization in a homogenizer in "Y" TE201/5 (Tecnal, Brazil) for 5 minutes, 28 samples of $1 \mathrm{~kg}$ were separated for moisture conditioning.

Extrusion was carried out using a complete line of Inbra RX50 (Inbramaq, São Paulo, Brazil) with a single extrusion screw, $130 \mathrm{~mm}$ barrel diameter, $440 \mathrm{~mm}$ extruder length, a hydraulic cooling system for temperature control, variable speed, and a $50 \mathrm{~kg}$ $\mathrm{h}^{-1}$ capacity. The extrusion process parameters were: Constant parameters: extrusion temperature in the $1^{\text {st }}\left(20\right.$ to $\left.25^{\circ} \mathrm{C}\right)$ and $2^{\text {nd }}$ zones $\left(45\right.$ to $\left.50^{\circ} \mathrm{C}\right)$; screw compression ratio $(3: 1)$; screw diameter $(32,6 \mathrm{~mm})$, die diameter $(3 \mathrm{~mm})$; feed rate $\left(150 \mathrm{~g} \mathrm{~min}^{-1}\right)$; and cutting speed (90rpm). Variable parameters: cassava leaf flour amount (\% wet basis), feed moisture (\%); barrel temperature in the $3^{\text {rd }}$ zone $\left({ }^{\circ} \mathrm{C}\right)$; and screw speed (rpm) (Table 1). Variation ranges between the upper and the lower limit of variables were established based on preliminary tests.

During the extrusion process a portion of the next test material was used to purge the extruder. A total of $500 \mathrm{~g}$ of extruded sample were collected after achieving steady-state flow in the extruder. The extruded samples were dried $\left(40^{\circ} \mathrm{C}\right)$ to the desired moisture $(8-9 \%)$ in an oven with air circulation (Marconi - MA037 Brazil). Each dried sample was powdered using a knife mill (Marconi-MA 680, Brazil) with screen of $468 \mathrm{~mm}$.

Water absorption index (WAI) and water solubility index (WSI) were assessed on raw materials and blends before and after extrusion process (ANDERSON et al., 1969). Water absorption index (WAI) is the weight of gel obtained per gram

Table 1 - Levels of variation and independent variables of the extrusion process.

\begin{tabular}{llllll}
\hline \multirow{2}{*}{ Independent variables } & \multicolumn{5}{c}{------ Levels of variation------ } \\
& 2 & -1 & 0 & +1 & 2 \\
\hline Cassava leaf flour $(\%)$ & 1.5 & 3 & 4.5 & 6 & 7.5 \\
Screw speed (rpm) & 175 & 189 & 203 & 217 & 231 \\
Extrusion temperature $\left({ }^{\circ} \mathrm{C}\right)$ & 60 & 70 & 80 & 90 & 100 \\
Moisture $(\%)$ & 20 & 22.5 & 25 & 27.5 & 30 \\
\hline
\end{tabular}


of dry ground sample. The water solubility index (WSI) is the percentage of dry matter recovered after the supernatant is evaporated from the water absorption determination.

Color measurements (CIE L*, $\mathrm{a}^{*}, \mathrm{~b}^{*}$ color space) were performed on raw materials and blends before extrusion and on ground extruded samples using a Minolta CR-400 model colorimeter (Konica Minolta, Ramsey, NJ, USA). The color of extrudates was expressed as the average of three $L^{*}, a^{*}$, and $b^{*}$ readings, where $\mathrm{L}^{*}$ stands for brightness, $+\mathrm{a}^{*}$ redness, $-a^{*}$ greenness, $+b^{*}$ yellowness, and $-b^{*}$ blueness. A white calibration plate was used to standardize the equipment prior to color measurements.

To evaluate the properties of extruded mixtures, a Rapid Visco Analyser (RVA), series 4, Newport Scientific (Warriewood, NSW, Australia), was used for starch suspensions $(3.5 \mathrm{~g}$ sample in $25 \mathrm{~mL} \mathrm{H}_{2} \mathrm{O}$ ) corrected to $140 \mathrm{~g} \mathrm{~kg}^{-1}$ wet basis. Ethanol (1g) was added to the sample, as recommended for the Extrusion 2 method. The apparent viscosity was expressed as rapid visco units (RVU), with one RVU equaling $12 \mathrm{cP}$.

Response Surface Methodology describes the behavior of a system in which the independent variables $\left(\mathrm{X}_{\mathrm{k}}\right)$ and the dependent variable or response $\left(\mathrm{Y}_{\mathrm{i}}\right)$ are combined. The response is a function of the levels at which those factors were combined and defined. Within the proposed variation ranges, i.e. within the region characterized by these levels, the behavior of each response can be predicted in a general form according to the equation:

$\mathrm{Y}_{1}=\mathrm{b}_{\mathrm{o}}+\mathrm{b}_{1} \mathrm{X}_{1}+\mathrm{b}_{2} \mathrm{X}_{2}+\mathrm{b}_{3} \mathrm{X}_{3}+\mathrm{b}_{4} \mathrm{X}_{4}+\mathrm{b}_{11} \mathrm{X}_{1}^{2}+$ $b_{22} X_{2}^{2}+b_{33} X_{3}^{2}+b_{44} X_{4}^{2}+b_{12} X_{1} X_{2}+b_{13} X_{1} X_{3}+b_{14} X_{1} X_{4}+$ $b_{23} X_{2} X_{3}+b_{24} X_{2} X_{4}+b_{34} X_{3} X_{4}+$ eWhere: $Y_{1}=$ Dependent variable or response function; $\mathrm{X}_{1}, \mathrm{X}_{2}, \mathrm{X}_{3}, \mathrm{X}_{4}=$ Values of the independent variables; $b_{0}=$ Coefficient relative to the line interception with the response axis; $b_{1}, b_{2}, b_{3}, b_{4}=$ Linear coefficients assessed through least square method; $b_{11}, b_{22}, b_{33}, b_{44}=$ Coefficients of quadratic variables; $b_{12}, b_{13}, b_{14}, b_{23}, b_{24}, b_{34}=$ Coefficients of interaction between independent variables; $\mathrm{e}=$ Experimental error.

The response surfaces plots were drawn from the adjusted models using the software Statistica ${ }^{\circledR}$ 6.0.

\section{RESULTS AND DISCUSSION}

The color analysis of raw materials before extrusion showed the high brightness of the cassava starch $(97.06 \pm 0.22)$, a $\mathrm{a}^{*}$ positive $(0.62 \pm 0.01)$ and $\mathrm{b}^{*}$ positive $(4.40 \pm 0.06)$. The luminosity $\left(\mathrm{L}^{*}\right)$ observed was higher than related by Leonel et al. (2009) for commercial cassava starch (92.21) which may be related to lower levels of non-starch components of the commercial product used in this study. The cassava leaf flour showed lowest luminosity $(47.52 \pm 0.13)$, presence of negative value of $a^{*}(-0.66 \pm 0.02)$ and presence of positive $b^{*}$ value $(15.97 \pm 0.03)$.

Water solubility index (WSI) and water absorption index (WAI) are two indices linked to the estimation of behavior of the material if further processed for use as a binder, stabilizer, or source of protein in beverages, health and nutrition bars, dairy, baked, and emulsified/ground meat food systems (OIKONOMOU \& KROKIDA, 2012). Results of these indexes for raw materials were $1.52 \pm 0.07 \%$ for WSI and $3.62 \pm 0.07 \mathrm{~g} \mathrm{gel} \mathrm{g}^{-1}$ for WAI in cassava starch and $14.85 \pm 0.12 \%$ for WSI and $6.87 \pm 0.27 \mathrm{~g} \mathrm{gel} \mathrm{g}^{-1}$ for WAI in cassava leaf flour. Low water absorption index and water solubility index in cassava starch before extrusion process were also found in other studies (LEONEL et al., 2009; MESQUITA et al., 2013). The highest values of WSI and WAI observed in cassava leaf flour can be due the high values of non-starch components.

Paste properties of cassava starch showed that the initial viscosity at $25^{\circ} \mathrm{C}$ was too close to zero due to the absence of gelatinized starch. The curve showed an acute peak (characteristic of starch granules presenting structural homogeneity) followed by a pronounced fall, even before reaching $95^{\circ} \mathrm{C}$, which revealed little stability of the hot paste during agitation. Viscosity peak of cassava starch was of $408.25 \pm 0.41 \mathrm{RVU}$, breakdown was of $277.9 \pm 0.62$ RVU, final viscosity was of $195.5 \pm 0.89$ RVU, retrogradation tendency $(\mathrm{R})$ was of $65.2 \pm 0.22$ RVU.As expected, all results of paste properties of cassava leaf flour were lower than those observed for cassava starch, showing low tendency of this flour for gel formation. It was observed $29.83 \pm 0.39 \mathrm{RVU}$ for viscosity peak, $5.92 \pm 0.31 \mathrm{RVU}$ for breakdown, $78.83 \pm 0.45$ RVU for final viscosity and $49.92 \pm 0.34$ for retrogradation tendency.

Color is an important characteristic of extruded foods. Color changes can give information about the extent of browning reactions such as caramelization, Maillard reaction, degree of cooking, and pigment degradation that take place during the extrusion process (ANTON et al., 2008). The values obtained in this study for the luminosity of extruded blends ranged from 35.97 to 47.64. Decrease in brightness to the extruded products was observed regardless of the treatment when compared to $\mathrm{L}^{*}$ of the mixtures before extrusion (87.26 to 92.93). The analysis of the coefficients of regression showed 
linear effect of the percentage of cassava leaf flour and extrusion temperature, as well as, quadratic effect of screw speed and effect of interaction of extrusion temperature and screw speed on this color parameter (Table 2). However, the model cannot be considered predictive (Lack of fit $<0.05$ ).

The results obtained for $a^{*}$ value of the extruded products ranged from 0.58 to 2.15. Analysis of the regression coefficients showed linear and quadratic effects of cassava leaf flour and moisture, linear effect of extrusion temperature and quadratic effect of screw speed, as well as, significant effects of interaction between leaf flour with screw speed and moisture (Table 2). Under low moisture and intermediate values of leaf flour, screw speed and temperature it was observed highest $\mathrm{a}^{*}$ values (Figure1).

The $\mathrm{b}^{*}$ values ranged from 8.30 to 17.38 . Data analysis showed linear effects of extrusion temperature and moisture, quadratic effect of screw speed and significant effects of interaction of temperature with moisture and screw speed (Table 2). Under extreme opposite conditions of temperature and moisture were observed the highest $b^{*}$ values (Figure 1).

High extrusion temperatures increase the color intensity and high moisture levels result in lighter products, since increased moisture reduces the residence time, with greater fluidity within the extruder, providing lower non-enzymatic browning of extruded products.

WSI and WAI values extend in a wide range of values depending on the specific parameters applied during each extrusion process. Factors affecting the values of these indices can be classified into two main groups: the first one consists of the parameters that are linked to the raw material and the second one includes parameters related to the extruder equipment. In particular, the first group refers to the initial composition of raw material, raw material formulation, pre-processing treatments and initial particle size of milled materials. The second group is related to the extruder conditions, such as extruder type, last section barrel temperature, feed moisture content, feed rate, screw speed, screw configuration, screw compression ratio, die dimension, and die configuration (SHARMA et al., 2004; OIKONOMOU \& KROKIDA, 2011).

The results obtained for the extruded mixtures showed WAI ranging from 15.21 to $22.22 \mathrm{~g}$ gel $\mathrm{g}^{-1}$. These values were higher than those found in the mixture before extrusion process which varied from 2.02 to $2.11 \mathrm{~g} \mathrm{gel} \mathrm{g}^{-1}$. The increase in the WAI after extrusion was also observed by SILVA \& ASCHERI (2009) who reported $2.36 \mathrm{~g} \mathrm{gel} \mathrm{g}^{-1}$ for raw flour of rice and a variation from 6.10 to $7.76 \mathrm{~g}$ gel $\mathrm{g}^{-1}$ after extrusion.

Analysis of the regression coefficients showed linear effects of leaf flour, extrusion temperature and moisture, quadratic effect of screw speed, and effects of interactions of temperature with rotation and moisture on the WAI (Table 2). Under conditions of high extrusion temperature and low moisture it is possible to observe higher values of WAI (Figure 1). Only gelatinized starch granules absorb water at room temperature and swell; however, starch fragmentation increases when the gelatinization degree increases, decreasing thus water absorption (LEONEL et al., 2009).

WSI is related to the amount of soluble solids on a dry sample allowing the verification of the

Table 2 - Mathematic models for the characteristics of the extruded $(\mathrm{P}<0.05)$.

\begin{tabular}{|c|c|c|c|c|}
\hline & 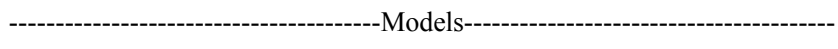 & $\mathrm{R}^{2}$ & $\mathrm{~F}_{\text {value }}$ & $\operatorname{Pr}>\mathrm{F}$ \\
\hline $\mathrm{L}^{*}$ & $\mathrm{Y}=42.34-1.34 \mathrm{~b}_{1}+1.35 \mathrm{~b}_{2}-1.15 \mathrm{~b}_{33}-1.50 \mathrm{~b}_{23}$ & 0.61 & 1.69 & 0.161 \\
\hline$a^{*}$ & $Y=1.22-0.16 b_{1}+0.15 b_{2}-0.13 b_{4}-0.13 b_{11}-0.15 b_{33}-0.14 b_{44}+0.12 b_{13}+0.12 b_{14}$ & 0.82 & 4.98 & 0.002 \\
\hline$b^{*}$ & $\mathrm{Y}=13.87+1.15 \mathrm{~b}_{2}+0.76 \mathrm{~b}_{4}-0.90 \mathrm{~b}_{33}-1.13 \mathrm{~b}_{23}-1.25 \mathrm{~b}_{24}$ & 0.70 & 2.38 & 0.050 \\
\hline WAI & $\mathrm{Y}=18.91-0.51 b_{1}+1.13 b_{2}+0.48 b_{4}-0.70 b_{33}-0.88 b_{23}-0.86 b_{24}$ & 0.72 & 2.53 & 0.043 \\
\hline WSI & $\mathrm{Y}=85.83+4.67 \mathrm{~b}_{3}$ & 0.66 & 3.66 & 0.008 \\
\hline IV & $\mathrm{Y}=8.70-0.99 \mathrm{~b}_{1}-0.15 \mathrm{~b}_{2}-1.90 \mathrm{~b}_{4}-0.93 \mathrm{~b}_{22}+1.99 \mathrm{~b}_{24}$ & 0.75 & 2.98 & 0.013 \\
\hline VP & $\mathrm{Y}=36.41-3.97 \mathrm{~b}_{3}-3.04 \mathrm{~b}_{22}+2.64 \mathrm{~b}_{12}-3.66 \mathrm{~b}_{23}+3.87 \mathrm{~b}_{24}$ & 0.79 & 3.43 & 0.012 \\
\hline B & $\mathrm{Y}=18.54-2.91 b_{3}+2.25 b_{4}+1.96 b_{12}-2.46 b_{23}+2.35 b_{24}-2.19 b_{34}$ & 0.80 & 3.17 & 0.016 \\
\hline PV & $\mathrm{Y}=17.96-1.02 \mathrm{~b}_{3}-1.76 \mathrm{~b}_{22}-0.97 \mathrm{~b}_{33}-1.17 \mathrm{~b}_{23}+1.55 \mathrm{~b}_{24}$ & 0.70 & 2.21 & 0.060 \\
\hline S & $\mathrm{Y}=0.05+0.06 \mathrm{~b}_{44}$ & 0.40 & 0.65 & 0.782 \\
\hline
\end{tabular}

$b_{1}=$ cassava leaf flour; $b_{2}=$ temperature; $b_{3}=$ screw speed; $b_{4}=$ moisture; $L^{*}=$ luminosity; $a^{*}=$ chroma $^{*} ; b^{*}=$ chroma $b^{*}$. WAI $=$ water absorption index; WSI $=$ water solubility index; $\mathrm{IV}=$ cold viscosity; $\mathrm{VP}=$ viscosity peak; $\mathrm{B}=$ breakdown; $\mathrm{FV}=$ final viscosity; $\mathrm{S}=$ setback; $\mathrm{R}^{2}=$ determination coefficient. 


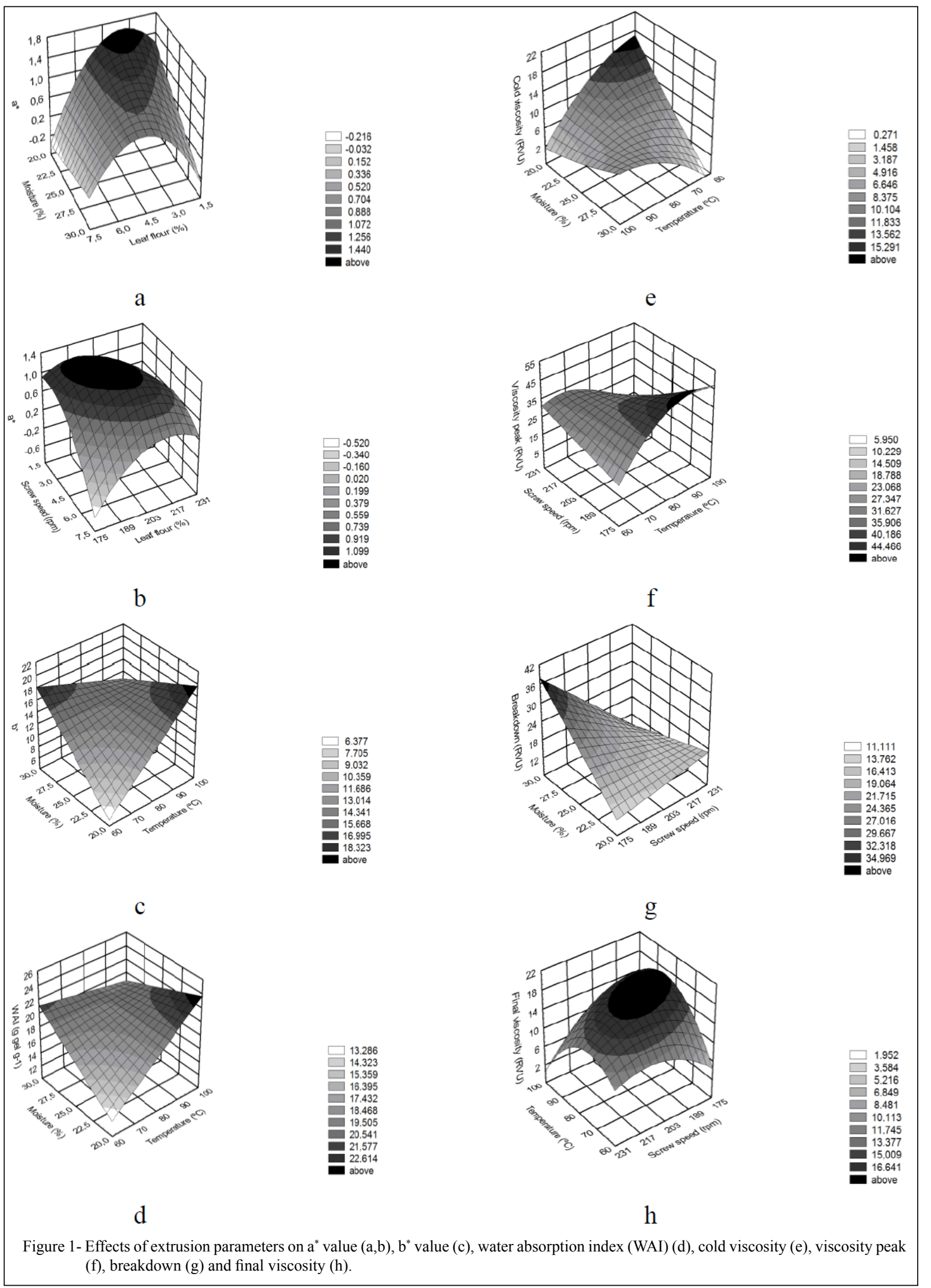

Ciência Rural, v.46, n.3, mar, 2016. 
severity of extrusion treatment. WSI of extruded blends ranged from 68.5 to $79.4 \%$ showing an increase of WSI with the extrusion process. Increasing of WSI after extrusion is the result of the severity of the treatments that can lead to degradation and solubilization of starch granules, protein and fiber present in the mixtures. The data analysis showed linear effect of screw speed on this parameter but the model cannot be considerable predictive (Lack of fit $<0.05$ ).

During extrusion, starch structures are disrupted and crystalline regions melted. After this melting process, high shear and high temperature conditions results in molecular disorder, improving the solubility (ZENG et al., 2011). Cooking degree of a product can be verified by determining the viscosity of a suspension sample which is subjected to controlled shear and at a temperature regime requiring interleaved cycles of low, high and low temperature.

RVA viscosity parameters of extruded and raw materials were significantly different. Initial cold viscosity was observed for all extrusion treatments. Cold viscosity of extruded blends ranged from 1.83 to $15.75 \mathrm{RVU}$ (21.96 to $189 \mathrm{cp}$ ). Analysis of the regression coefficients showed linear effects of leaf flour and moisture, linear and quadratic effects of extrusion temperature, as well as, the effect of interaction between extrusion temperature and moisture on the initial viscosity of extruded blends (Table 2). In conditions of low extrusion temperature and high moisture it was possible observe higher values of cold viscosity (Figure 1). The increase in extrusion temperature led to an increase of the initial viscosity and, above $70^{\circ} \mathrm{C}$ there was a tendency towards fall, indicating degradation of the crystalline structure. The results obtained in this study are in agreement with those observed by LEONEL et al. (2009).

The degradation of starch granules increases in a low moisture because the mechanical stress on the screw is larger. This is reflected in lower conditions of swelling of the starch granules and thereby the viscosity decreases. Likewise, the mechanical friction decreases with high moisture leading to less destruction of granules.

It was observed values of viscosity peak ranging from 20.08 to 63.25 RVU (240.96 to $759 \mathrm{cp}$ ). This results shows that the processing conditions provided high degradation of the starchy structure. Analysis of regression coefficients showed significant effects of screw speed (linear), extrusion temperature (quadratic) and interactions of leaf flour and temperature, as well as, temperature with screw speed and moisture (Table 2). Maximum gelatinization degree occurred when extrusion temperature and screw speed acted with extreme opposite values (Figure 1).

Breakdown of extruded products varied from 8.67 a 41.17 RVU. Analysis of regression coefficients showed significant effects of screw speed (linear), moisture (linear), and effects of interaction of leaf flour with temperature, temperature with screw speed and also screw speed with moisture (Table 2). Higher breakdown values were observed under conditions of high moisture and low screw speed (Figure 1). Low breakdown values occurred because degradation of the starchy fraction did not lead to significant viscosity peaks. The high moisture content in the feed might act as a lubricant and reduce the melt viscosity during extrusion leading to high breakdown viscosity values.

The final viscosity of extruded blends ranged from 9.50 to 25.33 RVU. It was observed effects of screw speed (linear and quadratic), extrusion temperature (quadratic) and interactions of temperature with screw speed and moisture (Table 2). Under intermediate conditions of temperature and screw speed it was observed higher values of final viscosity (Figure 1).

The retrogadation tendency values (setback) of the extruded products varied from 0 to 0.7 RVU. These low values indicated the severity of treatments. The model was not significant and cannot be considered predictive (Table 2).

\section{CONCLUSION}

Pre-gelatinized blends are products that form paste in cold water or are soluble (fully or partially) in cold water, so in all conditions it is possible to observe products with these characteristics. For rapid preparation products, treatments that have high cold viscosity and high water absorption index are the most suitable obtained with intermediated conditions of variables parameters tested. Products with low final viscosity can be used for products with high solids, as infant formulas and foods for special diets. These characteristics can be observed under low screw speed and extrusion temperature with moisture and cassava leaf flour in intermediate percentages.

\section{ACKNOWLEDGEMENTS}

The authors are grateful for the financial support provided by the Conselho Nacional de Desenvolvimento Científico e Tecnológico (CNPQ) - Brazil. 


\section{REFERENCES}

ANDERSON, R.A. et al. Gelatinization of corn grits by roll and extrusion cooking. Cereal Science Today, Minneapolis, v.14, p.4-11, 1969. Available from: <http://www.researchgate.net/publication/230111534 Gelatinization_of_Corn_Grits_by_Roll_Cooking_Extrusion_ Cooking_and_Steaming $>$. Accessed: nov.14, 2014.

ANTON, A.A. et al. Influence of added bean flour (Phaseolus vulgaris $\mathrm{L}$.) on some physical and nutritional properties of wheat flour tortillas. Food Chemistry, Oxford, v.109, p.33-41, 2008. Available from: $<$ http://www.sciencedirect.com/science/article/pii/ S0308814607012617>. Accessed: nov.14, 2014. doi: 10.1016/j. foodchem.2007.12.005.

FERRARI, A.C.et al. Physical properties of snacks made from cassava leaf flour. Semina. Ciências Agrárias, Londrina, v.35, p.317-326, 2014. Available from: <http://www.uel.br/revistas/uel/ index.php/semagrarias/article/view/14781/pdf_234>. Accessed: nov.14, 2014. doi: 10.5433/1679-0359.2014v35n1p317.

LEONEL, M.et al. Physical characteristics of extruded cassava starch. Scientia Agricola, Piracicaba, v.66, p.486493, 2009. Available from: <http://dx.doi.org/10.1590/S010390162009000400009>. Accessed: nov.14, 2014.

MESQUITA, C.B. et al Effects of processing on physical properties of extruded snacks with blends of sour cassava starch and flaxseed flour. Food Science Technology, Campinas v.33, n.3, p.404-410, 2013. Available from: <http://dx.doi.org/10.1590/ S0101-20612013005000073> Accessed: nov.14, 2014.

MOUQUET, C. et al. Ability of a “very low-cost extruder" to produce instant infant flours at small scale in Vietnam. Food Chemistry, Oxford, v.82, p.249-255, 2003. Available from: <http://www. sciencedirect.com/science/article/pii/S0308814602005459\#>. Accessed: nov.14, 2014. doi: 10.1016/S0308-8146(02)00545-9.

OIKONOMOU, N.A.; KROKIDA, M.K. Literature data of WAI and WSI of extrudate food products. International Journal of Food Properties, Philadelphia, v.14, p.199-240, 2011. Available from: <http://www.tandfonline.com/doi/pdf/
10.1080/10942910903160422>. Accessed: nov.14, 2014. doi: $10.1080 / 10942910903160422$.

SHARMA, H.R. et al. Physico-chemical characteristics of rice bran processed by dry heating and extrusion cooking. International Journal of Food Properties, Philadelphia, v.7, p.603-614, 2004. Available from: <http://www.tandfonline.com/doi/pdf/10.1081/JFP200033047>. Accessed: nov.14, 2014. doi: 10.1081/JFP-200033047.

SILVA, R.F.; ASCHERI, J.L.R. Extrusão de quirera de arroz para uso como ingrediente alimentar. Brazilian Journal of Food Technology, Campinas, v.12, p.190-199, 2009.Available from: $<$ http://bj.ital.sp.gov.br/artigos/html/busca/PDF/v12n3387a.pdf>. Accessed: nov.14, 2014. doi: 10.4260/BJFT2009800900012.

SINGH, S.et al. Nutritional aspects of food extrusion: a review. International Journal of Food Science and Technology, Oxford, v.42, p.916-929, 2007. Available from: <http://soiaefrutta.com/wpcontent/uploads/2013/06/A.5.7-Nutritional-food-extrusion.pdf $>$. Accessed: nov.14, 2014. doi: 10.1111/j.1365-2621.2006.01309.x.

SPINELLO, A.M. et al. Cassava and turmeric flour blends as new raw materials to extruded snacks. Ciência e Agrotecnologia, Lavras, v.38, p.68-75, 2014. Available from: <http://dx.doi.org/10.1590/ S1413-70542014000100008>. Accessed: nov.14, 2014.

TAVERNA, L.G. et al. Changes in physical properties of extruded sour cassava starch and quinoa flour blends. Food Science and Technology, Campinas, v.32, p.826-834, 2012. Available from: <http://dx.doi.org/10.1590/S0101-20612012005000113>. Accessed: nov.14, 2014.

VISSOTTO, F.Z. et al. Evaluation of the influence of lecithination and agglomeration on the physical properties of a cocoa powder beverage (cocoa powder beverage lecithination and agglomeration). Food Science and Technology, Campinas, v.26, p.666-671, 2006. Available from: <http://dx.doi.org/10.1590/ S0101-20612006000300028>. Accessed: jul.04, 2015.

ZENG, J.et al. Extruded corn flour changed the functionality behavior of blends. Czech Journal of Food Science, Prague, v.29, n.5, p.520527, 2011. Available from: <http://www.agriculturejournals.cz/ publicFiles/48211.pdf>. Accessed: nov.14, 2014. 